DOI: http://dx.doi.org/10.33846/hn41101

http://heanoti.com/index.php/hn

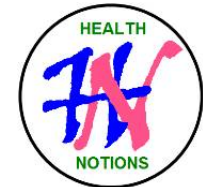

RESEARCH ARTICLE

URL of this article: http://heanoti.com/index.php/hn/article/view/hn41101

\title{
Usage of Foods for Special Medical Purposes in the Pediatric Ward Dr. Soetomo
} Hospital Surabaya

\begin{tabular}{c} 
Dwi Lestari Avianti( ${ }^{1(C A)}$, Nur Aisiyah Widjaja ${ }^{2}$, Roedi Irawan $^{\mathbf{3}}$ \\
Indonesia; aviantiped@ gmail.com (Corresponding Author) \\
${ }^{1(\mathrm{CA}) \text { Department of Pediatrics, Faculty of Medicine, Universitas Airlangga / Dr. Soetomo General Hospital, }}$ \\
${ }^{2}$ Department of Pediatrics, Faculty of Medicine, Universitas Airlangga / Dr. Soetomo General Hospital, Indonesia \\
${ }^{3}$ Department of Pediatrics, Faculty of Medicine, Universitas Airlangga / Dr. Soetomo General Hospital, Indonesia \\
\hline
\end{tabular}

\section{ABSTRACT}

Children who are hospitalized are at risk of malnutrition due to increased energy requirements caused by underlying disease, drug use, decreased appetite and inadequate diet during treatment which can inhibit growth and development. Medical nutrition is required to use food for special medical purposes (FSMP) to meet nutritional needs during hospitalization. The aim of this study is to know the number of patients and types of medical indications for FSMP administration. This research was conducted from August 2018 to October 2018 by reviewing the medical records of children who were treated in the pediatric ward Dr. Soetomo Surabaya. The inclusion criteria were children aged 1 month -18 years and received FSMP as indicated. The sampling method is total sampling. Data in the form of age, gender, nutritional status, disease diagnosis and FSMP type administration, were obtained from medical records from April 2017 to April 2018. The samples obtained were grouped according to indications for FSMP use based on the pediatric drug dosage book of the Indonesian Pediatric Association. A total of 402 children were enrolled in this study. Male patients who received FSMP were $229(56.9 \%)$. The highest use of FSMP was at the age of less than 1 year as many as 195 patients $(48.5 \%)$ with the highest indication of malnutrition. The most indications for FSMP are malnutrition as many as 267 patients (66.4\%), which was caused by gastrointestinal (GI) disease (24.4\%), malignancy (18.4\%) and congenital heart disease (CHD) (11.2\%). The second highest indication of FSMP was malabsorption in 210 patients $(52.2 \%)$, caused by gastrointestinal disease (41.4\%) and cholestasis $(17.6 \%)$. Another indication that there was volume limitation in 51 patients (12.7\%), mostly due to CHD accompanied by heart failure and cow's milk protein allergy (CMPA) in 38 patients (9.5\%), more with gastrointestinal symptoms $(60.5 \%)$ than respiratory symptoms $(39.5 \%)$. The use of FSMP in the pediatric ward Dr. Soetomo Hospital, Surabaya with medical indications of malnutrition (moderate malnutrition, severe malnutrition, failure to thrive), malabsorption, volume limitation and cow's milk protein allergy with malnutrition as the most indications.

Keywords: hospitalized children; medical nutrition; foods for special medical purposes; nutritional requirements

\section{INTRODUCTION}

Hospitalized children are at risk for malnutrition. Malnutrition during hospitalization can be caused due to increased energy requirements due to underlying disease, drug use, decreased appetite and inadequate diet during treatment ${ }^{(1)}$. Hospital malnutrition can increase the risk of infection, length of stay, care costs, disease complications, return to hospital care, the risk of death, as well as growth disorders, mental development, psychomotor and increased behavior problems ${ }^{(2)}$. Malnutrition in hospitalized children is not only a concern in low-resource areas, but in developed and developing countries ${ }^{(3)}$.

Research in several developed countries estimates the prevalence of malnutrition in children hospitalized to be between $12 \%$ and $24 \%{ }^{(4)}$. The prevalence of hospital malnutrition in developing countries in Thailand is $10-19 \%{ }^{(5)}$, Vietnam $19 \%^{(6)}$, and the prevalence varies in various regions in Indonesia. The prevalence of malnutrition in Makassar is up to $81.5 \%{ }^{(7)}$, Yogyakarta as much as $27 \%^{(8)}$, and in Denpasar as much as $17.5 \%$, in children who are treated for more than 14 days have a risk of experiencing home malnutrition illness as much as 8.1 times compared to less than 14 days $^{(9)}$. The prevalence of malnutrition in hospital Dr. Soetomo Surabaya before 2011 at the time before the development of Pediatric Nutritional Care (PNC) was still quite high, at $65 \%$. The incidence of malnutrition decreased in to $6.6 \%$ in $2017-2018^{(10)}$.

Studies in Ireland show that nutritional supplement prescribing has increased since the early 2000s, but physicians who prescribe do not carry out adequate nutritional monitoring ${ }^{(11)}$. Studies on the use of Oral

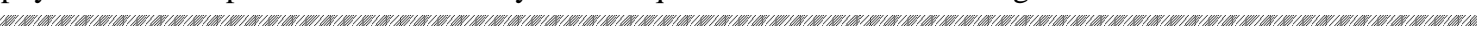


Nutrition Supplement (ONS) in hospitalized children aged 2 to 8 years showed an association between use of oral nutritional supplements and decreased length of stay (6.4 vs 7.5 days) and low costs hospitalization ${ }^{(2)}$. Studies on giving oral nutritional supplements to acute leukemia patients during remission-induction chemotherapy can improve children's nutritional status, reduce the incidence of complications, and reduce hospitalization $\operatorname{costs}^{(12)}$.

Pediatric Nutrition Care is carried out for both healthy and sick children. The use of PNC in hospitalized patients aims to prevent hospital malnutrition ${ }^{(13)}$. Every child has the right to survive, grow and develop optimally, children with malnutrition and/ or disease can cause nutritional problems that hinder growth and development so that efforts to overcome nutritional problems are needed. Based on these considerations, the Republic of Indonesia Minister of Health Regulation Number 29 of 2019 concerning overcoming nutritional problems for children due to disease was established ${ }^{(14)}$. Medical nutrition uses Foods for Special Medical Purposes (FSMP), which are special foods designed to help meet the nutritional or dietary needs of patients living with diseases, disorders or medical conditions that temporarily or permanently cannot achieve adequate nutritional intake from normal food or through modification of a normal diet ${ }^{(15)}$.

Based on these problems, it is necessary to conduct research to determine the number of patients and the types of medical indications for FSMP administration.

\section{METHODS}

This research was conducted from August 2018 to October 2018 by reviewing the medical records of pediatric patients who were treated in the pediatric ward at Dr. Soetomo General Hospital Surabaya. The inclusion criteria in this study were children aged 1 month -18 years and received FSMP as indicated. The sampling method is total sampling. Data collection used a data collection form regarding age, sex, nutritional status, disease diagnosis and FSMP type administration obtained from medical records from April 2017 to April 2018. Samples obtained were grouped according to indications of FSMP use use based on the pediatric drug dosage book of the Indonesian Pediatric Association.

Research ethics were obtained from the health research ethics committee of the Universitas Airlangga medical faculty/ Dr. Soetomo Regional General Hospital. This research has been carried out based on a certificate of ethical eligibility number 0451/ KEPK/ VIII/ 2018 dated 2 August 2018. Confidentiality of research subjects is well maintained by not mentioning names, but written based on initials. The data from this research are only used for research purposes.

Ethical clearance was pproved by Researched Ethical Committee Dr. Soetomo General Hospital Surabaya.

\section{Characteristics of Study Subjects}

\section{RESULTS}

There were 402 children aged 1 month - 18 years using FSMP in this study. The highest use of FSMP was at the age of less than 1 year as many as 195 patients $(48.5 \%)$ with the highest indication of malnutrition. The most indication of FSMP administration in malnutrition cases was 267 patients (66.4\%). Male patients who received FSMP were 229 (56.9\%). The characteristics of the research subjects are shown in table 1.

Table 1. Characteristics of study subjects

\begin{tabular}{|c|c|c|}
\hline Characteristics & Frequency & Percentage \\
\hline \multicolumn{3}{|l|}{ Age } \\
\hline 1 month - 1 year & 195 & 48.5 \\
\hline$>1$ year- 3 years & 78 & 19.4 \\
\hline$>3$ years- 5 years & 20 & 4.9 \\
\hline$>5$ years & 109 & 27.2 \\
\hline \multicolumn{3}{|l|}{ Gender } \\
\hline Boys & 229 & 56.9 \\
\hline Girl & 173 & 43.1 \\
\hline \multicolumn{3}{|l|}{ Nutritional status } \\
\hline Good nutritional status & 126 & 31.3 \\
\hline Moderate malnutrition & 129 & 30 \\
\hline Severe malnutrition & 133 & 33 \\
\hline Failure to thrive & 23 & 5.7 \\
\hline
\end{tabular}

\section{Indications for Use of FSMP}

The most indications for FSMP are malnutrition as many as 267 patients (66.4\%), malabsorption in 210 patients $(52.2 \%)$, volume limitation in 51 patients $(12.7 \%)$, and cow's milk protein allergy (CMPA) in 38 patients $(9.5 \%)$. The highest use of FSMP was at the age of less than 1 year as many as 195 patients $(48.5 \%)$ 
with the highest indication of malnutrition. The indication of malnutrition was $45.5 \%$ at the age of 1 month -1 year, the indication of malabsorption was $54.8 \%$ at the age of 1 month -1 year, the indication of volume limitation was $53 \%$ at the age of 1 month - 1 year and the indication for CMPA was $84.2 \%$ at 1 month - 1 year old.

Table 2. Indications for use of foods for special medical purposes

\begin{tabular}{ccc}
\hline FSMP indications & Frequency & Percentage \\
\hline Malnutrition (moderate malnutrition & 267 & 66.4 \\
severe malnutrition, failure to thrive) & & \\
1 month - 1 year & 121 & 45.5 \\
> 1 year-3 years & 43 & 16.1 \\
> 3 years-5 years & 17 & 6.4 \\
> 5 years & 86 & 32.2 \\
Volume Limitation & 51 & 12.7 \\
1 month - 1 year & 27 & 53 \\
> 1 year-3 years & 4 & 7.8 \\
> 3 years-5 years & 3 & 5.9 \\
> 5 years & 17 & 33.3 \\
Malabsorbtion & 210 & 52.2 \\
1 month - 1 year & 115 & 54.8 \\
$>$ 1 year-3 years & 48 & 22.9 \\
> 3 years-5 years & 8 & 3.8 \\
> 5 tahun & 39 & 18.5 \\
Cow's milk protein allergy/ CMPA & 38 & 9.5 \\
1 month - 1 year & 32 & 84.2 \\
> 1 year-3 years & 6 & 15.8 \\
\hline
\end{tabular}

The most malnutrition indications caused by gastrointestinal disease (24.4\%), malignancy (18.4\%) and congenital heart disease (CHD) (11.2\%). The most malabsorption indications were gastrointestinal (GI) disease (41.4\%) and cholestasis (17.6\%). Most indications for volume limitations are due to CHD cases accompanied by heart failure. The indication for CMPA is more with gastrointestinal symptoms $(60.5 \%)$ than respiratory symptoms $(39.5 \%)$.

Table 3. Types of disease indicated by foods for special medical purposes

\begin{tabular}{|c|c|c|c|c|}
\hline Disease & Malnutrition (\%) & Malabsorbtion (\%) & $\begin{array}{c}\text { Volume } \\
\text { limitation }(\%)\end{array}$ & $\begin{array}{c}\text { Cow's Milk } \\
\text { Protein Allergy/ } \\
\text { CMPA }(\%) \\
\end{array}$ \\
\hline Pneumonia,(\%) & $27 / 267(10 \%)$ & $11 / 210(5.2 \%)$ & 0 & 0 \\
\hline Congenital heart disease, $(\%)$ & $30 / 267(11.2 \%)$ & $9 / 210(4.3 \%)$ & $35 / 51(68.6 \%)$ & 0 \\
\hline Malignancy & $49 / 267(18,4 \%)$ & $23 / 210(11 \%)$ & $16 / 51(31.4 \%)$ & 0 \\
\hline Infections, (\%) & $27 / 267(10,2 \%)$ & $14 / 210(6.7 \%)$ & 0 & 0 \\
\hline Gastro intestinal problem, $(\%)$ & $65 / 267(24,4 \%)$ & $87 / 210(41.4 \%)$ & 0 & $23 / 38(60.5 \%)$ \\
\hline Chronic diarrhea & $32 / 65$ & $46 / 87$ & & \\
\hline Partial obstruction & $10 / 65$ & $17 / 87$ & & \\
\hline Vomiting & $6 / 65$ & $4 / 87$ & & \\
\hline $\begin{array}{l}\text { Inflammatory Bowel } \\
\text { Disease/ IBD }\end{array}$ & $5 / 65$ & $9 / 87$ & & \\
\hline $\begin{array}{l}\text { Short Bowel Syndrome/ } \\
\text { SBS }\end{array}$ & $5 / 65$ & $6 / 87$ & & \\
\hline GERD & $3 / 65$ & 2 & & \\
\hline Paralytic ileus & $2 / 65$ & 3 & & \\
\hline Abdominal TB & $2 / 65$ & 0 & & \\
\hline Cholestasis, (\%) & $26 / 267(9.7 \%)$ & $37 / 210(17.6 \%)$ & 0 & 0 \\
\hline Tuberculosis, (\%) & $6 / 267(2.3 \%)$ & $2 / 210(1 \%)$ & 0 & 0 \\
\hline Neurology cases, (\%) & $22 / 267(8.2 \%)$ & $15 / 210(7.1 \%)$ & 0 & 0 \\
\hline Hematology Cases, (\%) & $7 / 267(2.6 \%)$ & $4 / 210(1.9 \%)$ & 0 & 0 \\
\hline Marasmus-Kwasiorkor, (\%) & $8 / 267(3 \%)$ & $8 / 210(3.8 \%)$ & 0 & 0 \\
\hline Asthma, (\%) & 0 & 0 & 0 & $15 / 38(39.5 \%)$ \\
\hline
\end{tabular}

\section{Characteristics of Study Subjects}

DISCUSSION

In this study, FSMP was given to pediatric inpatients ranging in age from 1 month to 18 years. It was found that 402 patients received FSMP with different indications. Most of the age groups were prescribed FSMP in all indications of the administration, namely in the 1 month -1 year age group with the highest 
indication of malnutrition. Male were 229 patients (56.9\%) and female were 173 patients (43.1\%). Study by Lakdawalla et al on the effect of ONS use on length of stay in hospitalized children aged 2-8 years, as many as 6066 children received prescription ONS, female sex as much as $45.8 \%$ and male the remaining $54.2 \%{ }^{(2)}$. Another study by Pham et al evaluated the use of ONS in the growth of 121 children aged 24-48 months with stunting, as many as $49 \%$ of male subjects and $51 \%$ of female subjects ${ }^{(16)}$.

Most of the age groups were prescribed FSMP in all indications of the administration, namely in the 1 month -1 year age group as many as 195 patients (48.5\%) with the highest indication of malnutrition. The most malnutrition indications caused by gastrointestinal disease $(24.4 \%)$, malignancy $(18.4 \%)$ and Congenital heart disease (CHD) (11.2\%). Malnutrition associated with childhood illness can be caused by loss of nutrition, increased energy expenditure, decreased nutritional intake, or changes in nutrient utilization. It can be caused by acute conditions such as trauma, burns, and infections, as well as chronic diseases such as cystic fibrosis, chronic kidney disease, malignancy, CHD, GI disease, and neuromuscular disease ${ }^{(17)}$.

\section{Use of Food for Special Medical Purposes as Indicated}

In this study, the indication for FSMP administration was based on the pediatric drug dosage book of the Indonesian Pediatric Association. FSMP was administered to malnutrition as many as 267 patients (66.4\%), volume limitation in 51 patients $(12.7 \%)$, malabsorption in 210 patients $(52.8 \%)$ and CMPA in 38 patients $(9.5 \%)$.

Study by Davaera et al on children aged 3 to 6 years, used ONS for children with mild-moderate malnutrition $^{(18)}$. Study by Vandenplas et al regarding the administration of semi-elemental formulas to inpatients of inpatients aged 23 weeks with GI problems including gastroenteritis, food allergies and chronic diarrhea ${ }^{(19)}$. Infants with congenital heart disease have a higher energy expenditure than normal babies, as a consequence of congestive heart failure and pulmonary hypertension. Although these babies need more nutrition than normal babies, they also experience fluid restriction, which can hinder the provision of adequate nutrition so that CHD babies are often malnourished and fail to thrive. Taniguchi-Fukatsu et al study of 21 CHD infants, compared the provision of a standard density formula $(0.67 \mathrm{kcal} / \mathrm{mL})$ with a high density formula $(0.77-1.03 \mathrm{kcal} / \mathrm{mL})$, then analyzed the safety parameters (serum creatinine, BUN, ALT, AST and frequency of vomiting/ diarrhea) and effectiveness parameters (energy and protein intake, fluid volume, weight gain, and serum albumin). There was no clinical evidence of the side effects of using high density formulas. The use of high-density formulas can safely increase nutrient intake and increase weight in infants with $\mathrm{CHD}^{(20)}$.

Cow's milk protein allergy is the most common food allergy in childhood with a prevalence between $1.9 \%$ and $4.9 \%$. Most of the children showing symptoms of CMPA are less than 1 year old, so they may need a hypoallergenic formula. The hypoallergenic formula includes an extensive hydrolyze formula (EHF) and an amino acid formula (AAF). In most of the children with CMPA, EHF was sufficient for symptom resolution, but in some children the symptoms were not relieved by EHF and thus required AAF. The indications for AAF are symptoms are not completely resolved in EHF, faltering growth / failure to thrive, elimination of many foods, food allergy to severe complex gastrointestinal complexes, eosinophilic esophagitis, food protein-induced enterocolitis syndrome, severe eczema, and symptoms appear when breastfeeding. In children with anaphylaxis, even with limited evidence, AAF is still recommended ${ }^{(21)}$.

Indications for giving FSMP according to the IDAI pediatric drug dosage book are for cow's milk allergy, malabsorption, malnutrition, growth failure, volume limitations, congenital metabolic diseases, intractable seizures and supplementation of growth catch-up in premature babies ${ }^{(22)}$. The indication of FSMP provision is in accordance with the Regulation of the Minister of Health of the Republic of Indonesia Number 29 of 2019 concerning overcoming nutritional problems for children due to disease, namely in patients with risk of growth failure, malnutrition or malnutrition, very premature babies, very low birth weight babies (VLBW), CMPA and inherited metabolic disorders. FSMP for growth failure, malnutrition and malnutrition in the form of ONS with an energy content greater than $0.9 \mathrm{kcal} / \mathrm{ml}$. FSMP for very premature babies and VLBW is in the form of premature formula with the provision of a minimum energy content of $24 \mathrm{kcal} / 30 \mathrm{ml}$ and/ or a nutritional complement to breast milk (human milk fortifier). FSMP for CMPA is a cow's milk-based formula with extensive hydrolyzed protein or free amino acids. FSMP for inherited metabolic disorders is a formula with a macronutrient and micronutrient composition that matches the inherited metabolic disorder suffered ${ }^{(14)}$.

\section{CONCLUSION}

The use of FSMP in the pediatric ward Dr. Soetomo Hospital, Surabaya with medical indications of malnutrition (moderate malnutrition, severe malnutrition, failure to thrive), malabsorption, volume limitation and CMPA with malnutrition as the most indications.

\section{REFERENCES}

1. Beser OF, Cokugras FC, Erkan T, Kutlu T, Yagci RV. TUHAMAR Study Group. Evaluation of malnutrition development risk in hospitalized children. Nutrition. 2017;1-30. 
2. Lakdawalla DN, Mascarenhas M, Jena AB, Vanderpuye-Orgle J, LaVallee C, Linthicum MT, et al. Impact of oral nutrition supplements on hospital outcomes in pediatric patients. Journal of Parenteral and Enteral Nutrition. 2014;20:1-8.

3. McCarthy A, Delvin E, Marcil V, Belanger V, Marchand V, Boctor D, et al. Prevalence of malnutrition in pediatric hospitals in developed and in-transition countries: the impact of hospital practices. Nutrients. 2019;11:1-18.

4. Shaughnessy EE, Kirkland LL. Malnutrition in hospitalized children: a responsibility and opportunity for pediatric hospitalists. Hospital Pediatrics. 2016;6:1-7.

5. Sukhosa O, Kittisakmontri K. Prevalence of hospital malnutrition at admission and outcomes in pediatric patients. International Journal of Child Health and Nutrition. 2017;6:98-104.

6. Huong PTT, Lam NT, Thu NN, Quyen TC, Lien DTK, Anh NQ, et al. Prevalence of malnutrition in patients admitted to a major urban tertiary care hospital in Hanoi, Vietnam. Asia Pacific Journal of Clinical Nutrition. 2014;23:437-44.

7. Wahyudin AJ, Lisal JS. Hospital malnutrition at pediatric ward dr. Wahidin Sudirohusodo hospital Makassar. International Journal of Pediatric Endocrinology. 2013;1:49.

8. Maryani E, Prawirohartono EP, Nugroho S. Faktor prediktor malnutrisi rumah sakit pada anak. Sari Pediatri. 2016;18:278-84.

9. Girsang SN, Sidiartha IGL. The Incidence of in-hospital malnutrition in children at Sanglah hospital Denpasar and its association with length of stay. Medicina. 2017;48:98-102.

10. Rekam Medik RSUD Dr. Soetomo 2018.

11. Loane D, Flanagan G, deSiu A, Mc Namara E, Kenny S. Nutrition in the community - an exploratory study of oral nutritional supplements in a health board area in Ireland. Journal of Human Nutrition and Dietetics. 2004; 17:257-66.

12. Liang R, Chen GY, Fu SX, Zhong J, Ma Y. Benefit of oral nutritional supplements for children with acute lymphoblastic leukaemia during remission-induction chemotherapy: a quasi-experimental study. Asia Pacific Journal of Clinical Nutrition. 2018;27:144-7.

13. UKK Nutrisi dan Penyakit Metabolik Ikatan Dokter Anak Indonesia. Rekomendasi ikatan dokter anak indonesia: asuhan nutrisi pediatrik (pediatric nutrition care). Ikatan Dokter Anak Indonesia. Jakarta. 2011.1-14.

14. Menkes RI. Peraturan Menteri Kesehatan Republik Indonesia Nomor 29 tahun 2019 tentang Penanggulangan Masalah Gizi bagi Anak Akibat Penyakit. 2019.

15. British Specialist Nutrition Association. The value of foods for special attention: medical purposes. 2016;910.

16. Pham DT, Hoang TN, Ngo NT, Nguyen LH, Tran TQ, Pham HM, et al. Effect of oral nutritional supplementation on growth in vietnamese children with stunting. The Open Nutrition Journal. 2019;13:4352.

17. Mehta NM, Corkins MR, Lyman B, Malone A, Goday PS, Carney L, et al. Defining pediatric malnutrition: a paradigm shift toward etiology-related definitions. Journal of Parenteral and Enteral Nutrition. 2013;37:460-81.

18. Davaera Y, Syaharusta DM, Jatmiko HK, Sjarif DR. Comparing compliance and efficacy of isocaloric oral nutritional supplementation using $1.5 \mathrm{kcal} / \mathrm{ml}$ or $1 \mathrm{kcal} / \mathrm{ml}$ sip feeds in mildly to moderately malnourished Indonesian children: a randomized controlled trial. Pediatric Gastroenterology Hepatology and Nutrition. 2018;21:315-20.

19. Vandenplas Y, Plaskie K, Hauser B. Safety and adequacy of a semi-elemental formula for children with gastro-intestinal disease. Amino Acids. 2010;38:909-14.

20. Taniguchi-Fukatsu A, Matsuoka M, Amagai T. Effect of a high density formula on growth and safety in congenital heart disease infants. e-SPEN, the European e-Journal of Clinical Nutrition and Metabolism. 2010;5:281-3.

21. Meyer R, Groetch M, Venter C. When should infants with cow's milk protein allergy use an amino acid formula? A practical guide. The Journal of Allergy and Clinical Immunology: in Practice. 2018;6:383-99.

22. Ikatan Dokter Anak Indonesia. Buku saku dosis obat pediatri. Jakarta. 2016.1-91. 